\title{
Airtightness of Residential Buildings in Finland
}

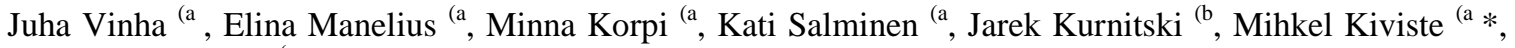 \\ Anssi Laukkarinen ${ }^{(a}$ \\ a) Tampere University of Technology, Department of Civil Engineering, P.O. Box 600, FI-33101, Tampere, \\ Finland \\ b) Aalto University, Department of Civil and Structural Engineering, P.O. Box 11000, FI-00076 Aalto, \\ Finland \\ * Corresponding author. Phone: +358 40373 2514, E-mail: mihkel.kiviste@ @ut.fi
}

\begin{abstract}
Single-family buildings and apartments in multi-family apartment buildings have been studied in Finland in two large-scale studies between the years 2002 and 2009. This paper is based on the measurements of airtightness of 170 single-family detached houses and 56 apartments by fan pressurisation method at $50 \mathrm{~Pa}$.

The mean air change rate of 10 autoclaved aerated concrete block, 10 shuttering concrete block, 10 concrete element, 10 brick masonry, 10 lightweight aggregate concrete block, 100 timber-framed, and 20 log single-family houseswas $1.5 \mathrm{~h}^{-1}, 1.6 \mathrm{~h}^{-1}, 2.6 \mathrm{~h}^{-1}, 2.8 \mathrm{~h}^{-1}, 3.2 \mathrm{~h}^{-1}, 3.9 \mathrm{~h}^{-1}$ and $6.0 \mathrm{~h}^{-1}$, respectively. In concrete-built multi-storey houses, in which the intermediate floor was cast on site, the mean $\mathrm{n}_{50^{-}}$-value of 23 apartments was $0.7 \mathrm{~h}^{-1}$. The mean $\mathrm{n}_{50}$-value of 20 apartments in multi-storey houses built from concrete elements was $1.6 \mathrm{~h}^{-1} .16$ apartments in timber-framed multi-storey houses had a mean $\mathrm{n}_{50}$-value $2.9 \mathrm{~h}^{-1}$.

Factors like construction method and insulation material (polyurethane insulation) in timber-framed houses, seam insulation material in log houses and ceiling structure in heavyweight buildings among others were found to have an effect on the average values of air change rates. The mean values of airtightness do not satisfy the recommended level of airtightness in Finland. Most important result, however, is that good airtightness of individual houses was reached within all house groups regardless of the choice of structure, storeys, ventilation system or technology of construction.
\end{abstract}

KEYWORDS: airtightness, air leakage, air change rate, residential buildings

\section{INTRODUCTION}

Increased awareness of public on energetic and environmental issues has led to considerable development of research on improving the energy performance of buildings. The European Directives on the energy performance of buildings (EPB) [1] state the need for a correct energetic diagnosis to improve the performance of existing buildings and their facilities. EPB largely depend on the Heating, Ventilation and Air Conditioning systems (HVAC), which in turn affect the Indoor Environmental Quality (IEQ). The ventilation is also affected by the uncontrolled air leakage (i.e. airtightness) across the building envelope that can bring to excessive energy consumptions due to air infiltrations from the outside. Also, airtightness affects EPB because it influences the ability of heat storage of the building.

Several studies on the building air tightness and related measurement techniques are available in international literature; most of them have been carried out at cold climatic conditions such as in Northern Europe, Canada, and US [2], [3], [4], [5]. Over the last years the studies on airtightness in building envelopes has included also in Southern Europe [6], [7] and Northern Asia [8].

Tampere University of Technology and Aalto University (former Helsinki University of Technology) have carried out two large- scale studies between years 2002 and 2009. In a study "Airtightness, indoor climate and energy efficiency of residential buildings", funded by Tekes (Finnish Funding Agency of Technology and Innovation) as well as 24 Finnish companies and associations, the indoor and outdoor climates, indoor moisture excess, ventilation performance, energy consumption and airtightness of 70 Finnish heavyweight single-family buildings and 56 apartments in multifamily apartment buildings were studied between years 2005 and 2009. This research project is closely related to a previous study 
"Moisture-proof healthy detached house", in which the same field measurements were carried out in 100 lightweight single-family buildings between years 2002 and 2005. Current paper is reporting the measurements of airtightness of both abovementioned research projects.

Heavyweight buildings is an abbreviated phrase for buildings, in which the external walls are constructed using heavyweight construction systems. In this study heavyweight buildings is a common phrase for buildings with precast concrete element, masonry brick (calcium silicate and burnt clay), block (autoclaved aerated concrete (AAC), lightweight aggregate concrete (LWAW) and shuttering concrete) and log external walls. Respectively, an abbreviation - lightweight buildings - is also used; however the only example of lightweight buildings in current study is timber-frame buildings. Both single-family and multifamily apartment buildings in current study include either heavyweight or lightweight external wall structures.

The main aim of these studies was to determine the current level of airtightness in modern singlefamily houses and apartments in Finland to:

- determine air tightness values of single-houses and apartments and to compare airtightness of different envelope structures

- determine typical distribution of air leakages in single-houses and apartmens with different envelope structures

The influence of different comparison variables was studied as follows:

1) envelope structures (timber-frame, log, concrete element, concrete block, brick masonry, AAC and LWAC);

2) joints of ceiling and wall structures (timber-frame, concrete and AAC ceiling);

3) floor structures (concrete slab on ground, concrete with crawl space, timber-framed with crawl space);

4) storeys (single-storey, multi-storey);

5) age (year of construction);

6) ventilation system (mechanical supply and exhaust, mechanical exhaust, natural ventilation);

7) air barrier and insulation material (plastic film and mineral wool, paper sheet and cellulose, polyurethane);

8) technology of construction (on site, prefabricated large elements, prefabricated small elements, pre-cut elements).

Mechanical ventilation is dominating in modern Finnish dwellings. Natural ventilation is remaining mainly in the older houses. Indoor environmental quality is affected by outdoor air from every uncontrolled leaks of the building envelope.

In 2007 a revised National Building Code of Finland (part C3) introduced a recommendation for airtightness. The air change rate at $50 \mathrm{~Pa}$ i.e. $\mathrm{n}_{50}$-value is recommended to be as near as possible to the value of one air change per hour in order to guarantee a proper function of ventilation devices [9]. The National Building Code of Finland (part D3) [10] takes into consideration leakage air flow in compensation calculation of heat loss. In new instructions the significance of airtightness of building envelope will be even more important than earlier. Therefore one aim of the research was also to determine the distribution of air leakages in buildings so that airtightness in problem places of each type of houses could be improved.

\section{STUDIED HOUSES}

The measurements were performed in two different studies. The measurement methods were the same and the measurements were carried out by mainly the same researcher group. However the selection of type of houses had some discrepancies. The measured houses were recruited mainly from the databases of manufacturers of the houses. Some of the houses were recruited also by delivering brochures to the dwellers of suitable looking houses. The houses were located mainly in the Tampere and Helsinki region.

\subsection{Lightweight (timber-framed) single family buildings}

The group of 100 buildings were chosen in order to represent wide selection of different timber-framed dwellings. The whole group of houses is not a random sample of Finnish timber-framed housing stock because the purpose was to gather enough subgroups of different wall structures (water vapour permeable walls and walls with water vapour barrier). Timber-framed dwellings differed from each other, for instance, as of age, ventilation type and structural solutions.

Three of the dwellings were non single family (one semi-detached and two terrace houses) buildings and some of the two-storey buildings had a first storey built of shuttering concrete or LWAC blocks. $48 \%$ 
of the houses were one-storey. $60 \%$ of the houses had a mechanical supply and exhaust ventilation system with heat recovery, $30 \%$ houses had a mechanical exhaust ventilation system and $10 \%$ had natural ventilation. Half of the houses were constructed on site, one fourth from large prefabricated elements and one fourth from either small prefabricated elements or with pre-cut -method. Most of the dwellings were built rather recently. The mean age of the dwellings was five years and the median was three years. Timber-framed buildings included some older houses with natural ventilation which were built in the beginning of 1980's.

Half of the houses were situated in the Tampere region, and half in the Helsinki region. Measurements were performed in two sets, in the summers of 2002 and 2003. [11]

\subsection{Heavyweight single family houses}

The group of 70 heavyweight houses consists of 20 log houses, 10 houses built from blocks of autoclaved aerated concrete (AAC), 10 houses built from lightweight aggregate concrete (LWAC), 10 houses built from bricks ( 5 from calcium silicate brick, 5 from burnt clay brick), 10 houses built from shuttering concrete blocks and 10 houses built from concrete elements. The abovementioned materials describe the main construction material applied in external walls. Three studied log houses had internal and one had external supplementary insulation. The external walls of the other log houses (16) as well as AAC houses (10) were homogeneous. The log houses were selected so that they had different types of seam insulation materials. Rest of the houses (40) in this group had a thermal insulation layer between the inner and outer material layer at the external wall structure. LWAC and shuttering concrete blocks were prefabricated meaning that the insulation layer was included in blocks during the manufacturing process. [12]

Ten (of 12) two-storey log houses had a timber-framed upper floor. Also four of the two-storey houses had a ground floor constructed of different construction material. 55 houses (of 70) had a timber-framed ceiling structure. Nine AAC external-walled houses (of 10) had also a reinforced AAC ceiling structure. Three houses with shuttering concrete block, two houses with concrete element and one house with LWAC exterior walls had a concrete hollow core slab as a ceiling structure. [12]

65 houses (of 70) had a mechanical supply and exhaust ventilation with heat recovery while five houses had a mechanical exhaust ventilation system. The average internal volume used in pressurisation test results was in $\log$ houses $483 \mathrm{~m}^{3}$ and in the rest of the houses $554 \mathrm{~m}^{3}$. All of the houses were relatively new; the oldest house was built 10 years prior to measurements. The mean age of the houses was 3 years and the median 2 years. Measurements were done in two sets, in the years 2005...2007. [12-15]

\subsection{Apartments}

56 apartments were measured in 16 buildings. Apartments measured in this study represent three different types of multi-storey buildings. Concrete element buildings (5) had concrete element external walls and hollow core ceiling slabs. Second group of apartments were in buildings, with also concrete element walls, but cast on site concrete ceilings (7). The only exception was a building (coded 6200), which had non-bearing timber-framed external walls. Third group of apartments were in timber-framed (4) multi-storey houses. [12]

Three to five apartments were chosen to be studied from the same building. When possible, the apartments were chosen from different floors so that one apartment was from the ground floor, one from the upper floor and one from a floor in-between. 14 studied buildings were constructed in 2000's and two buildings in 1990's. At the time of measurements the average age of buildings was 2.3 years (median 1 year). The average floor area of the apartments was $72 \mathrm{~m}^{2}$, ranging from $35 \mathrm{~m}^{2}$ to $138 \mathrm{~m}^{2}$. [12-15]

\section{PRESSURISATION TESTS}

The airtightness of the houses was tested using a fan pressurisation method according to European standard EN 13829 [16]. Fan pressurisation method is a widely used method and a relatively simple way of getting a comparative value of airtightness. Tests were done with a commercial computer-controlled blower-door system (Figure 1). During a blower-door test, all openings in the envelope are closed and sealed when needed. A fan is mounted airtightly on one of the building's door or window frames. Then, a 
pressure difference between the inside and the outside and the airflow through the fan, which is needed to maintain a certain pressure difference, are measured. In the apartments the fan was mounted on the door between apartment and staircase.

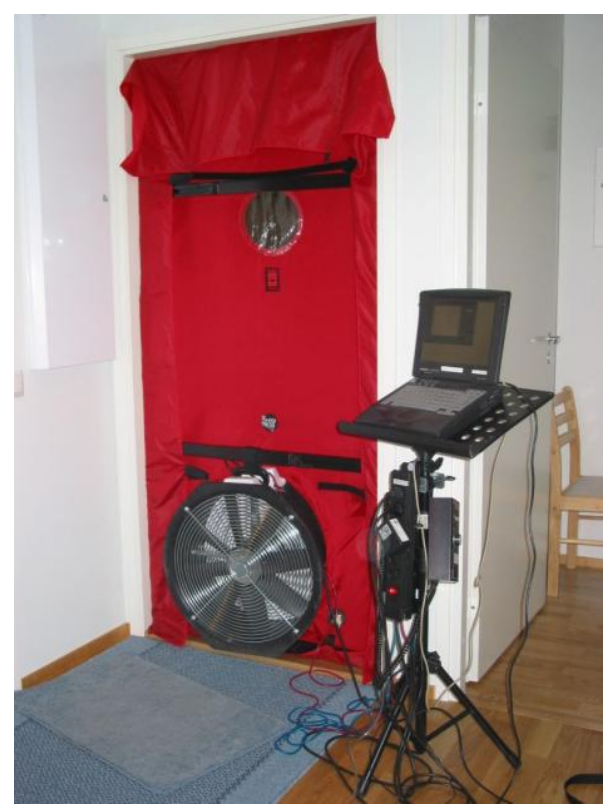

Figure 1. Blower-door system installed on door frames.

As a result of the pressurisation test a series of pressure differences and the corresponding airflows through the fan are received. A so-called building leakage curve could be calculated as:

$$
\dot{V}=C \cdot \Delta p^{n}
$$

where

$\dot{\mathrm{V}} \quad$ is the airflow required to maintain a pressure difference $\Delta \mathrm{p}=50 \mathrm{~Pa}\left[\mathrm{~m}^{3} / \mathrm{h}\right]$;

C flow coefficient $\left[\mathrm{m}^{3} /(\mathrm{h} \cdot \mathrm{Pa})^{\mathrm{n}}\right]$;

$\Delta \mathrm{p} \quad$ pressure difference between outdoor and indoor air $[\mathrm{Pa}]$;

$\mathrm{n} \quad$ exponent (depends on type of air flow, varying from 0.5 (laminar) to 1.0 (turbulent)).

Based on the test results a curve was fitted automatically by the blower-door software. Airflow corresponding to a pressure difference of $50 \mathrm{~Pa}$ can be divided by the inner volume of the measured building (equation 2). This quantity is called air change rate at $50 \mathrm{~Pa}$ (or air leakage rate at $50 \mathrm{~Pa}$, ACH50, $\mathrm{n}_{50}$-value), which enables comparison of airtightness values of different buildings. Air change rate at $50 \mathrm{~Pa}$ can be calculated as:

$$
\mathrm{n}_{50}=\frac{\dot{\mathrm{V}}_{50}}{\mathrm{~V}}
$$

where

$\mathrm{n}_{50} \quad$ air change rate at $50 \mathrm{~Pa}\left[\mathrm{~h}^{-1}\right]$;

$\dot{\mathrm{V}}_{50} \quad$ airflow required to maintain a pressure difference $\Delta \mathrm{p}=50 \mathrm{~Pa}\left[\mathrm{~m}^{3} / \mathrm{h}\right]$;

$\mathrm{V} \quad$ inner volume of the measured building $\left[\mathrm{m}^{3}\right]$. 
Airflow measured in a pressurisation test can also be normalised by the area of the envelope (air permeability at $50 \mathrm{~Pa}$, also called as air leakage index). The latter has also become a common way of reporting airtightness especially in Europe. Air leakage index can be calculated as:

$$
\mathrm{q}_{50}=\frac{\dot{\mathrm{V}}_{50}}{\mathrm{~A}_{\mathrm{v}}}
$$

where

$\mathrm{q}_{50} \quad$ air leakage index at $50 \mathrm{~Pa}\left[\mathrm{~m}^{3} /\left(\mathrm{hm}^{2}\right)\right]$, also $\left[1 /\left(\mathrm{sm}^{2}\right)\right]$;

$\mathrm{A}_{\mathrm{v}} \quad$ area of envelope of building/ measured structure $\left[\mathrm{m}^{2}\right]$.

The results and comparison between different building types in this article are mainly reported as air change rates. The inner volume of a single family house was calculated including the partition walls, fixture and fittings but excluding the intermediate floors. The area of the building envelope was calculated by using inner measures of envelope assemblies. This internal surface area included walls, ceiling and floors. The inner volume of an apartment was calculated multiplying floor area by the average room height.

In most of the cases the airtightness of a dwelling was tested with both pressurisation and depressurisation tests. Normally an appropriate way to give the result would be to give the mean value of these tests. The results in this paper are expressed as mean value for heavyweight buildings and apartments. Only the results of depressurization test were applied because these were performed in all (100) timberframed buildings. However, both pressurization and depressurization test was done in 75 timber-framed buildings and the difference between mean $\mathrm{n}_{50^{-}}$-values of pressurization $(3.8319 \mathrm{~h}-1)$ and depressurization test (3.8493 h-1) was only $0.45 \%$. EN 13829 [16] estimates the accuracy of final result of a pressurisation test to be within $\pm 15 \%$ in calm weather. Former Swedish standard estimates the accuracy of final result of a pressurisation test to be within $\pm 10 \%$ [17].

The equipment records normal pressure conditions (between indoor and outdoor air) prior and after switching the fan. Temperature conditions and size of building were inserted to blower-door software after which programme will correct air flows and enter results. The air flows were measured in series with at least five pressure differences $(10-60 \mathrm{~Pa})$. The air flow through the fan could be regulated in increments by placing the limiter collars. The software calculates an average of 100 measurement results taken in short period of each pressure difference increment.

Airtightness of the staircase was measured with two alternative methods: blower-door equipment and air supply unit of the measured house. Before the test air supply unit was centrally closed and mail box holes in doors were kept open. The exhaust fan of elevator shaft and replacement air ventilator were closed at the roof. The blower-door equipment was mounted on door frames between staircase and entrance door. Test with air supply unit of the house was started by closing incoming air ventilator in air supply unit and regulating exhaust air flow. Exhaust air flow was measured with the help of pressure differences measured in exhaust air fan. During the test the direction of leakage air was from staircase to apartments and through exhaust ducts to air supply ventilator. The highest pressure difference measured with air supply unit between indoor and outdoor air was approximately $25 \mathrm{~Pa}$. The $\mathrm{n}_{50}$-value was determined by fitting the curve to Equation 1, which is corresponded to measured pressure differences.

\section{RESULTS AND DISCUSSION}

\subsection{Single-family detached houses}

\subsubsection{Distributions, normal probability plots and hypothesis tests}

First the normality of the distributions were analysed. Figure 2 shows the distributions and normal probability plots of air change rate $[1 / \mathrm{h}]$ and air permeability $\left[\mathrm{m}^{3} /\left(\mathrm{hm}^{2}\right)\right]$ for timber-framed, and heavyweight houses. The results of hypothesis testing is presented as a package of four different tests; each with two different methods (Table 1). 

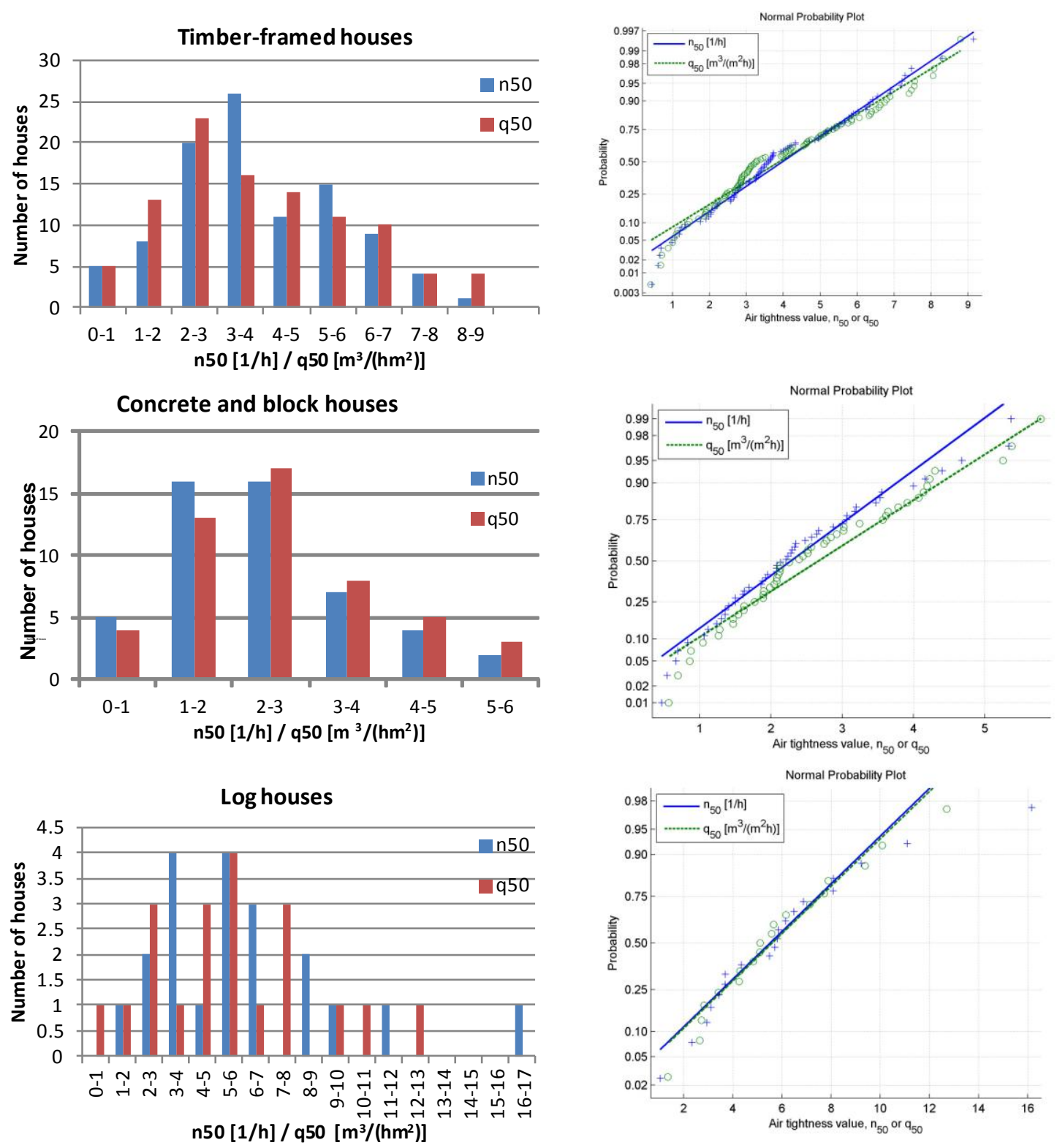

Figure 2 Distributions (left) and normal probability plots (right) of air change rate and air permeability of timber-framed, stone and $\log$ houses.

The null hypothesis is that the measurement data comes from a normal distribution. Different hypothesis tests use different methods, but in general the main idea is to calculate a test statistic that describes the differences between the two samples that are being compared. For example the Kolmogorov-Smirnov test uses the maximum value of the absolute differences between the two cumulative distribution functions. If the test statistic is larger than some predefined limit value, evidence is acquired that the two samples are not similar and null hypothesis could be rejected. Other method is to compare the corresponding probability (pvalue) of receiving a test statistic as large or larger from the other known or estimated distribution. If the pvalue is small, it means that it is unlikely to get the acquired result by chance and in that case the null hypothesis can be rejected. The h-value is a boolean variable with one (1) meaning that we have evidence to reject the null hypothesis and zero (0) meaning that we don't have enough evidence to reject it. 
Table 1. Hypothesis tests for the air change $\left(\mathrm{n}_{50}\right)$ and air permeability rates $\left(\mathrm{q}_{50}\right)$ of timber-framed, concrete and block and log houses.

\begin{tabular}{|l|l|l|l|l|l|l|l|}
\hline \multirow{2}{*}{ Test name } & \multicolumn{2}{l}{ Timber-frame houses } & \multicolumn{2}{l|}{$\begin{array}{l}\text { Concrete and block } \\
\text { houses }\end{array}$} & \multicolumn{2}{l|}{ Log houses } \\
\cline { 2 - 9 } & $\mathbf{n}_{\mathbf{5 0}}(\mathrm{n}=100)$ & $\mathbf{q}_{\mathbf{5 0}}(\mathrm{n}=99)$ & $\mathbf{n}_{\mathbf{5 0}}(\mathrm{n}=50)$ & $\mathbf{q}_{\mathbf{5 0}}(\mathrm{n}=50)$ & $\mathbf{n}_{\mathbf{5 0}}(\mathrm{n}=20)$ & $\mathbf{q}_{\mathbf{5 0}}(\mathrm{n}=19)$ \\
\hline $\begin{array}{l}\text { Kolmogorov- } \\
\text { Smirnov test }\end{array}$ & $\mathbf{h}$ & 0 & 1 & 0 & 0 & 0 & 0 \\
\cline { 2 - 9 } & $\mathbf{p}$-value & 0.1138 & 0.0474 & 0.466 & 0.3704 & 0.726 & 0.7888 \\
\hline $\begin{array}{l}\text { Anderson- } \\
\text { Darling test }\end{array}$ & $\mathbf{h}$ & 1 & 1 & 0 & 0 & 0 & 0 \\
\cline { 2 - 9 } & $\mathbf{p}$-value & 0.0476 & 0.0016 & 0.1007 & 0.0611 & 0.1029 & 0.4759 \\
\hline Lilliefors test & $\mathbf{h}$ & 1 & 1 & 0 & 1 & 0 & 0 \\
\cline { 2 - 9 } & $\mathbf{p}$-value & 0.0016 & 0.001 & 0.0842 & 0.0438 & 0.296 & 0.3765 \\
\hline $\begin{array}{l}\text { Jacque-Bera } \\
\text { test }\end{array}$ & $\mathbf{h}$ & 0 & 0 & 0 & 0 & 1 & 0 \\
\cline { 2 - 9 } & $\mathbf{p}$-value & 0.167 & 0.0517 & 0.0589 & 0.0854 & 0.0122 & 0.1608 \\
\hline
\end{tabular}

$\mathrm{h}=1 \quad$ Null hypothesis of normally distributed values is rejected at 0.05 significance level.

$\mathrm{h}=0 \quad$ Null hypothesis of normally distributed values is not rejected at 0.05 significance level.

The h-values in Table 1 show that the null hypothesis of normality has been rejected in total of seven times (out of 24) at 0.05 significance level; more commonly (five out of eight) in the timber-frame buildings. The $\mathrm{h}$-values depend on the chosen significance level. If the significance level is changed to 0.01 (or 0.1 ), the null hypothesis is rejected 3 times out of 24 (or 12 out of 24). On the other hand this means that in multiple cases the null hypothesis is not rejected. The choice of significance level is subject to discussion, but it seems that the airtightness values should be described with some other than normal distribution. The normal distribution can work as a first guess, but more sophisticated calculations should use some other distribution, that inherently produces continuous and non-negative values.

Some tests have different rejection outcomes for $\mathrm{n}_{50}$ and $\mathrm{q}_{50}$ values within the same external wall stucture. Since the building shape varies between studied cases, the relationship between $\mathrm{n}_{50}$ and $\mathrm{q}_{50}$ is not a constant value and, thus, cannot be taken out from the test statistic formulas. This has caused a nonlinear transformation of values and the differences in the results of different hypothesis tests.

\subsubsection{Influence of external wall structures}

Figures 3 and 4 show the summary of airtightness of measured single-family detached houses on the basis of their different external wall structures. Figure 3 shows slight difference in bar plots of average air change rates ( $\mathrm{n}_{50}$ values) between two groups of external wall structures - concrete (-based) and block walls vs. log and timber-framed walls. Timber-framed houses and log houses have on average higher air permeability values.Log houses were found to be the leakiest and varying house type in current study. The reason for large range within the studied log houses was the use of different seals. Log houses with modern seals (cellular rubber or expanding seam insulation) were clearly more airtight when compared to conventional seals (mineral wool, flax insulation or polypropylene).

However, quite good airtightness is reached within each group, which mean that good air tightness can be reached regardless of the choice of structure. It should be noted that the sample size of some sub-groups of external wall structures is relatively small. Other influential factors of airtightness (such as construction year and floor area) were limited as much as possible by careful selection of case buildings; however not fully eliminated, otherwise the sample size of a specific sub-group would be insufficient. 


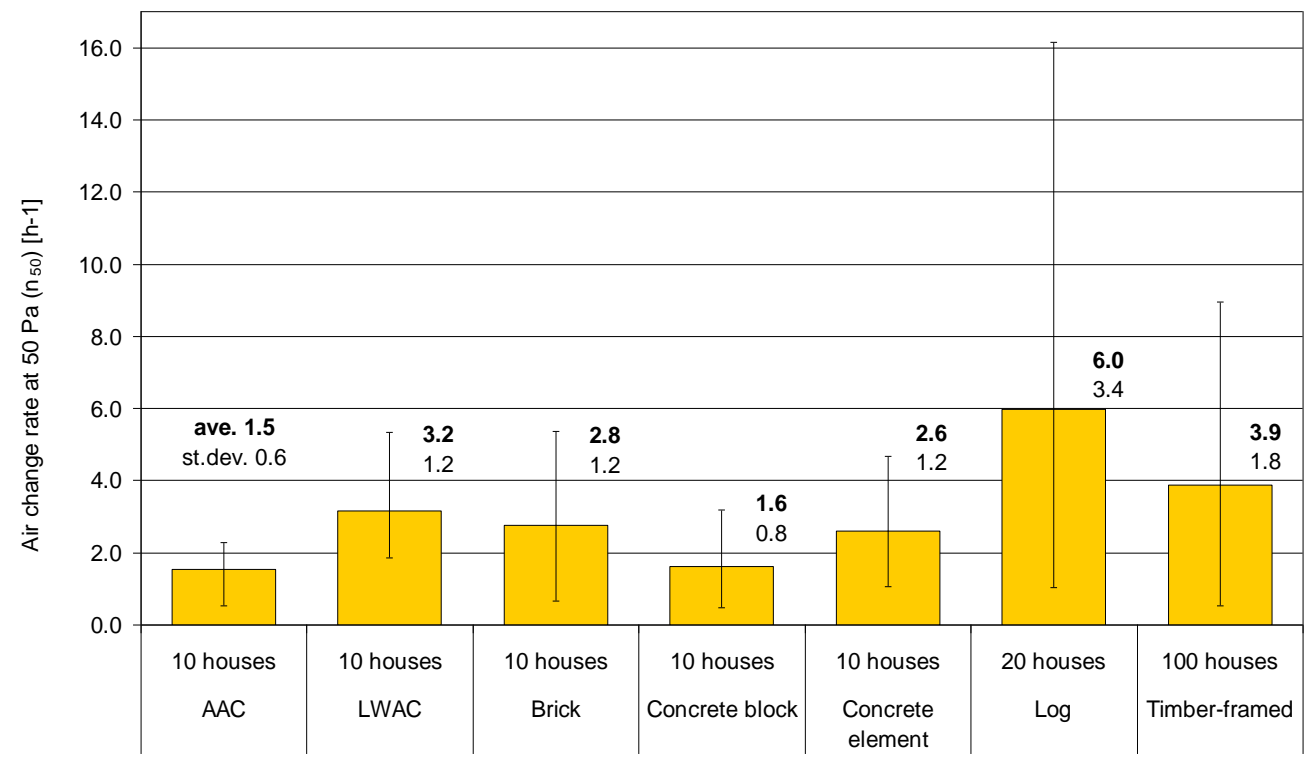

Figure 3. Air change rates of single-family detached houses normalized by indoor volume $\left(\mathrm{n}_{50}\right)$. Bold numbers indicate the average values and regular numbers beneath show standard deviations. "Whiskers" show the range of the results.

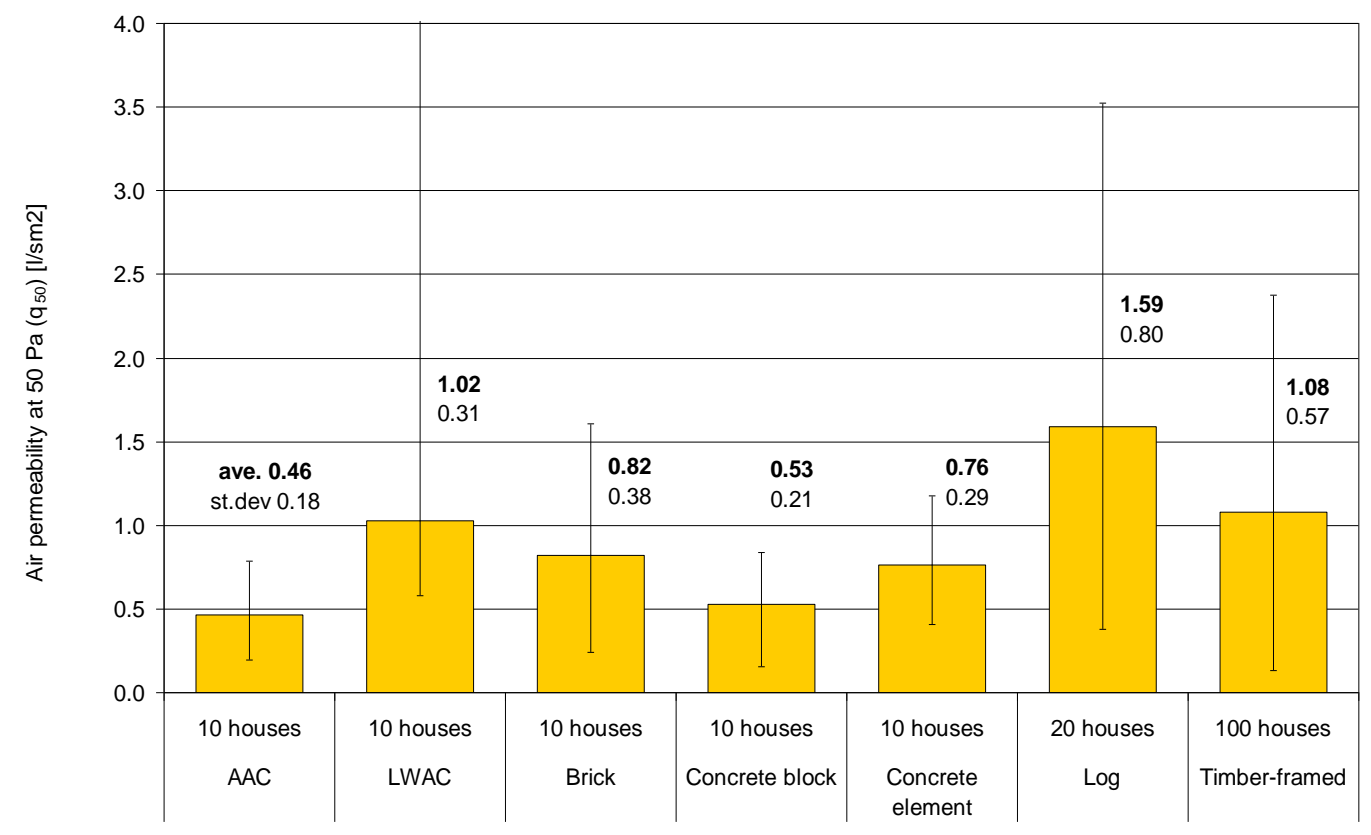

Figure 4. Air leakage indices of single-family detached houses normalised by envelope area $\left(\mathrm{q}_{50}\right)$. Bold numbers indicate the average values and regular numbers beneath show standard deviations. "Whiskers" show the range of the results.

\subsubsection{Influence of storeys and intermediate ceiling joint}

The impact of the number of storeys and the impact of intermediate floor were also studied. Table 2 divides single-family detached houses into one-storey and multi-storey buildings. The group of multi-storey buildings consists of at least $1 \frac{1}{2}$-storey houses. Timber-framed buildings with polyurethane wall insulation (6 houses) were not included in comparison, because they were notably airtighter than the others and all of them were multi-storey except for one. 
Table 2. Air change rates and air leakage rates at $50 \mathrm{~Pa}\left[\mathrm{~h}^{-1}\right]$ of one-storey and multi-storey houses.

\begin{tabular}{|c|c|c|c|c|c|c|}
\hline \multirow[t]{2}{*}{ Type of house } & \multicolumn{3}{|c|}{ One-storey houses } & \multicolumn{3}{|c|}{ Multi-storey houses } \\
\hline & $\begin{array}{l}\text { Amount } \\
\text { of } \\
\text { houses }\end{array}$ & $\begin{array}{l}\text { Average } \\
\mathrm{n}_{50} \text {-value } \\
{\left[\mathrm{h}^{-1}\right]}\end{array}$ & $\begin{array}{l}\text { Average } \\
\mathrm{q}_{50}-\text { value } \\
{\left[1 / \mathrm{sm}^{2}\right]}\end{array}$ & $\begin{array}{l}\text { Amount } \\
\text { of } \\
\text { houses }\end{array}$ & $\begin{array}{l}\text { Average } \\
\mathrm{n}_{50} \text {-value } \\
{\left[\mathrm{h}^{-1}\right]}\end{array}$ & $\begin{array}{l}\text { Average } \\
\mathrm{q}_{50} \text {-value } \\
{\left[1 / \mathrm{sm}^{2}\right]}\end{array}$ \\
\hline $\begin{array}{l}\text { Autoclaved } \\
\text { aerated } \\
\text { concrete }\end{array}$ & 3 & 2.0 & 1.8 & 7 & 1.3 & 1.6 \\
\hline $\begin{array}{l}\text { Lightweight } \\
\text { aggregate } \\
\text { concrete }\end{array}$ & 2 & 4.4 & 4.6 & 8 & 2.9 & 3.5 \\
\hline Brick & 4 & 2.7 & 2.5 & 6 & 2.8 & 3.2 \\
\hline $\begin{array}{l}\text { Shuttering } \\
\text { concrete block }\end{array}$ & 2 & 2.4 & 2.2 & 8 & 1.4 & 1.8 \\
\hline $\begin{array}{l}\text { Concrete } \\
\text { element }\end{array}$ & 4 & 3.3 & 2.9 & 6 & 2.2 & 2.6 \\
\hline $\begin{array}{l}\text { Concrete and } \\
\text { masonry houses } \\
\text { in total }\end{array}$ & 15 & 2.9 & 2.7 & 35 & 2.1 & 2.5 \\
\hline $\log$ & $8 / 7^{(1}$ & 7.3 & 6.0 & 12 & 5.1 & 5.6 \\
\hline Timber-framed & 46 & 3.8 & 3.4 & $48 / 47^{(1}$ & 4.4 & 4.8 \\
\hline
\end{tabular}

T) The envelope areas of one timber-framed house and one log house were not determined, so the sample number for the calculation of $\mathrm{q}_{50}$-value of $\log$ houses was 68 and of timber-framed houses 47 .

In the whole study of single-family detached houses, one-storey houses (average $\mathrm{n}_{50}=3.7 \mathrm{~h}^{-1}$, table 2) did not appear to be significantly airtighter in comparison with two-storey houses (average $\mathrm{n}_{50}=4.1 \mathrm{~h}^{-1}$, table 2). Table 2 shows that the number of storeys had an influence on the air change rates of different single-family detached house types (concrete and masonry, log and timber-framed houses) although the differences of averages were not statistically significant between each group. The average air change rate $\left(\mathrm{n}_{50}\right)$ of multistorey concrete, block, and log houses was smaller than that of one-storey houses. Opposite effect was noticed at the timber-framed houses. The difference of averages was statistically significant as regards to the concrete and masonry houses in total (t-test, $\mathrm{p}$-value $<0.05$ ).

The inner volume of the houses increased in relation to the area of envelope instead and this in turn reduced the air change rate (see equations 2 and 3). This can be noticed when considering the $\mathrm{q}_{50}$-values which did not decrease as much as the $\mathrm{n}_{50}$-values. In the comparison of the average $\mathrm{q}_{50}$-values the number of storeys was statistically insignificant in all but timber-framed house types.

Intermediate ceiling-wall joint weaken the airtightness of multi-storey timber-framed buildings so much that the average air change rate $\left(\mathrm{n}_{50}\right.$-value $)$ increased although the inner volume also increased. The influence of storeys was not statistically significant considering the $\mathrm{n}_{50}$-values but it was remarkably significant concerning the $\mathrm{q}_{50}$-values (t-test, $\mathrm{p}$-value < 0.001 ) of timber-framed buildings. This result is understandable because the intermediate ceiling-wall joint of timber-framed structure is difficult to seal especially when intermediate floor joists rest on a wall structure [18]. Therefore, the quality of work is a significant factor, but rather difficult to measure.

The volume of concrete and masonry houses in proportion to area of envelope was on average greater than the volume of the log and the timber-framed houses. In theory for example a house shaped like cube conforms better to requirements set for $\mathrm{q}_{50}$-value compared to more multiform houses. The same phenomenon explains why multi-storey heavyweight houses were significantly airtighter than one-storey houses when comparing only the $\mathrm{n}_{50}$-values. The difference was not significant when also $\mathrm{q}_{50}$-values were 
compared (Table 2). The inner volume (average $554 \mathrm{~m}^{3}$ ) of the measured concrete and block houses was also on average greater than log houses (average $483 \mathrm{~m}^{3}$ ) or timber-framed houses (average $405 \mathrm{~m}^{3}$ ). Concrete and masonry houses with greater volume had slightly smaller (weak correlation) $n_{50}$-value. The volume of timber-framed houses did not have an influence to $\mathrm{n}_{50}$-value.

\subsubsection{Influence of floor stuctures and year of construction}

In Table 3 the air change rates of concrete and block houses with slab-on ground and concrete crawl space floor structure are compared. On the study of average air change rates the influence of floor structure was not statistically significant. The sample sizes were small with a large variation among the house groups.

Table 3. Air change rates at $\left.50 \mathrm{~Pa}^{[-1}\right]$ of concrete and masonry houses with slab-on ground or concrete crawl space floor structure.

\begin{tabular}{|l|c|c|l|l|l|l|}
\hline \multirow{2}{*}{$\begin{array}{l}\text { Type of } \\
\text { house }\end{array}$} & \multicolumn{3}{|l|}{ Houses with slab-on ground } & \multicolumn{3}{l|}{ Houses with concrete crawl space } \\
\cline { 2 - 7 } & Amount of & $\begin{array}{l}\text { Average } \\
\mathrm{n}_{50}-\text { value } \\
{\left[\mathrm{h}^{-1}\right]}\end{array}$ & $\begin{array}{l}\text { Average } \\
\mathrm{q}_{50}-\text {-value } \\
{\left[1 / \mathrm{sm}^{2}\right]}\end{array}$ & $\begin{array}{l}\text { Amount of } \\
\text { houses }\end{array}$ & $\begin{array}{l}\text { Average } \\
\mathrm{n}_{50} \text {-value } \\
{\left[\mathrm{h}^{-1}\right]}\end{array}$ & $\begin{array}{l}\text { Average } \\
\mathrm{q}_{50} \text {-value } \\
{\left[1 / \mathrm{sm}^{2}\right]}\end{array}$ \\
\hline $\begin{array}{l}\text { Autoclaved } \\
\text { aerated } \\
\text { concrete }\end{array}$ & 6 & 1.5 & 1.7 & 4 & 1.7 & 1.7 \\
\hline $\begin{array}{l}\text { Concrete } \\
\text { element }\end{array}$ & 6 & 2.2 & 2.5 & 4 & 3.2 & 3.2 \\
\hline $\begin{array}{l}\text { Lightweight } \\
\text { aggregate } \\
\text { concrete }\end{array}$ & 9 & 3.1 & 3.6 & 1 & 4.2 & 4.3 \\
\hline Total & $\mathbf{2 1}$ & $\mathbf{2 . 4}$ & $\mathbf{2 . 7}$ & $\mathbf{9}$ & $\mathbf{2 . 6}$ & $\mathbf{2 . 6}$ \\
\hline
\end{tabular}

Table 4 shows comparative results of air change rates of the timber-framed houses with slab-on ground, concrete crawl space and timber-framed crawl space floor structures. Buildings with polyurethane wall insulation (6 houses) were not taken into comparison because they were substantially airtighter than the houses with plastic air barrier. The houses which floor structure consisted of both structures (slab-on ground and crawl space) were taken into account in both groups. The houses with slab-on ground (nonaerated) were slightly airtighter than the houses with aerated timber-framed floor structure, but this difference was not either statistically significant. The differences between the air leakage indices $\left(\mathrm{q}_{50}\right)$ of the different floor structures were negligible.

Table 4. Air change rates at $50 \mathrm{~Pa}\left[\mathrm{~h}^{-1}\right]$ of timber-framed houses with slab-on ground, concrete crawl space or timber-framed crawl space floor structure.

\begin{tabular}{|l|l|l|l|l|l|l|l|l|l|}
\hline \multirow{2}{*}{$\begin{array}{l}\text { Type of } \\
\text { house }\end{array}$} & \multicolumn{3}{|l|}{ Houses with slab-on ground } & \multicolumn{3}{l|}{$\begin{array}{l}\text { Houses with concrete crawl } \\
\text { space }\end{array}$} & \multicolumn{3}{l|}{$\begin{array}{l}\text { Houses with timber-framed } \\
\text { crawl space }\end{array}$} \\
\cline { 2 - 10 } & $\begin{array}{l}\text { Amount } \\
\text { of } \\
\text { houses }\end{array}$ & $\begin{array}{l}\text { Ave. } \\
\mathrm{n}_{50} \\
- \text {-value } \\
{\left[\mathrm{h}^{-1}\right]}\end{array}$ & $\begin{array}{l}\text { Ave. } \\
\mathrm{q}_{50} \\
- \text {-value } \\
{\left[1 / \mathrm{sm}^{2}\right]}\end{array}$ & $\begin{array}{l}\text { Amount } \\
\text { of } \\
\text { houses }\end{array}$ & $\begin{array}{l}\text { Ave. } \\
\mathrm{n}_{50} \\
- \text { value } \\
{\left[\mathrm{h}^{-1}\right]}\end{array}$ & $\begin{array}{l}\text { Ave. } \\
\mathrm{q}_{50} \\
- \text {-value } \\
{\left[1 / \mathrm{sm}^{2}\right]}\end{array}$ & $\begin{array}{l}\text { Amount } \\
\text { of } \\
\text { houses }\end{array}$ & $\begin{array}{l}\text { Ave. } \\
\mathrm{n}_{50} \\
- \text { value } \\
{\left[\mathrm{h}^{-1}\right]}\end{array}$ & $\begin{array}{l}\text { Ave. } \\
\mathrm{q}_{50} \\
- \text {-value } \\
{\left[1 / \mathrm{sm}^{2}\right]}\end{array}$ \\
\hline $\begin{array}{l}\text { Timber- } \\
\text { framed }\end{array}$ & $69 / 68^{(1}$ & $\mathbf{4 . 0}$ & 4.2 & 13 & $\mathbf{4 . 2}$ & 4.3 & 18 & $\mathbf{4 . 4}$ & 4.3 \\
\hline
\end{tabular}

1) The envelope area of one timber-framed house was not determined, so the sample for the calculation of $\mathrm{q}_{50}$-rate was 68.

The year of construction was not statistically significant to the airtightness of timber-framed (regression: $\mathrm{n}_{50}, \mathrm{p}$-value $=0.10 ; \mathrm{q}_{50}, \mathrm{p}$-value $=0.70$ ) or massive (regression: $\mathrm{n}_{50}, \mathrm{p}$-value $=0.67 ; \mathrm{q}_{50}, \mathrm{p}$ value $=0.70$ ) buildings. That was expected, because the amount of older houses in current study was too small (modern houses were aimed). Therefore no age versus airtightness conclusions can be drawn based on the studied buildings. 


\subsubsection{Influence of ventilation system, type of insulation and technology of construction of timber- framed houses}

More thorough analysis is performed with timber-framed houses as follows. Most of the timber-framed houses had a mechanical ventilation system. The average airtightness values of timber-framed houses with mechanical ventilation were significantly different (smaller) than the houses with natural ventilation (ttests, $\mathrm{n}_{50}$ : $\mathrm{p}$-value $<0.001 ; \mathrm{q}_{50}$ : $\mathrm{p}$-value $<0.01 ;$ Figure 5). The age of the dwellings might have some effect on these results. The mean age of timber-framed houses with natural ventilation was 11 years, with mechanical exhaust ventilation 5 years and with mechanical supply and exhaust ventilation 4 years. The mean air change rate of timber-framed houses with mechanical supply and exhaust ventilation was lowest, $3.6 \mathrm{~h}^{-1}$. However, also in this group there is still room for a lower level of airtightness that is substantial for the proper function of ventilation devices.

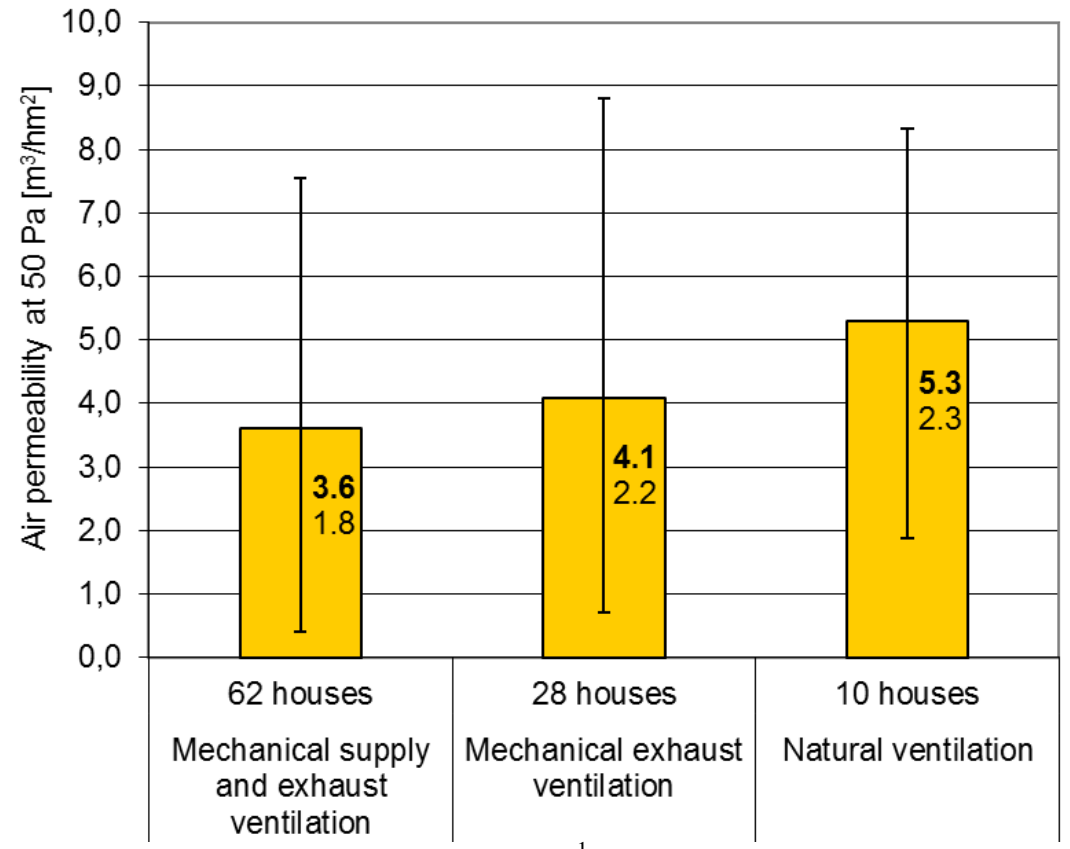

Figure 5. Air change rate at $50 \mathrm{~Pa}\left[\mathrm{~h}^{-1}\right]$ of timber-framed houses grouped by ventilation system. Bold numbers indicate the average values and regular numbers beneath show standard deviations. "Whiskers" show the range of the results.

Typical air seals applied in studied timber-framed buildings are a paper sheet and a plastic film, which also acts as a vapour barrier. Some of the studied houses have no additional air seal. In those houses the inner board (usually gypsum board panel) acts as an air barrier. In a few of the houses the thermal insulation material also acts as an air barrier.

Figure 6 is a plot of the average air change rates grouped by different combinations of insulation materials and air barriers. Current analysis was performed at houses with the same insulation material and air barrier applied both in ceiling and wall structures. The most common combination of insulation material and air barrier was mineral wool (rock wool or glass wool) and a plastic film. The second most common combination was cellulose (loose fill) insulation and a construction paper sheet air barrier. Third category included houses with aluminium covered polyurethane insulation, which also functions as an air barrier. In over one third of the total of 100 houses a mixture of different insulation materials and air barriers had been used. Clearly the lowest air change rates were reached at houses with polyurethane insulation. The average air change rate of this group was significantly better than the houses with mineral wool and plastic film (ttest, $\mathrm{n}_{50}, \mathrm{p}$-value $<0.001$ ) or cellulose insulation and paper sheet (t-test, $\mathrm{n}_{50}, \mathrm{p}$-value $<0.001$ ). The difference of average air change rates of two latter groups was not statistically significant. 


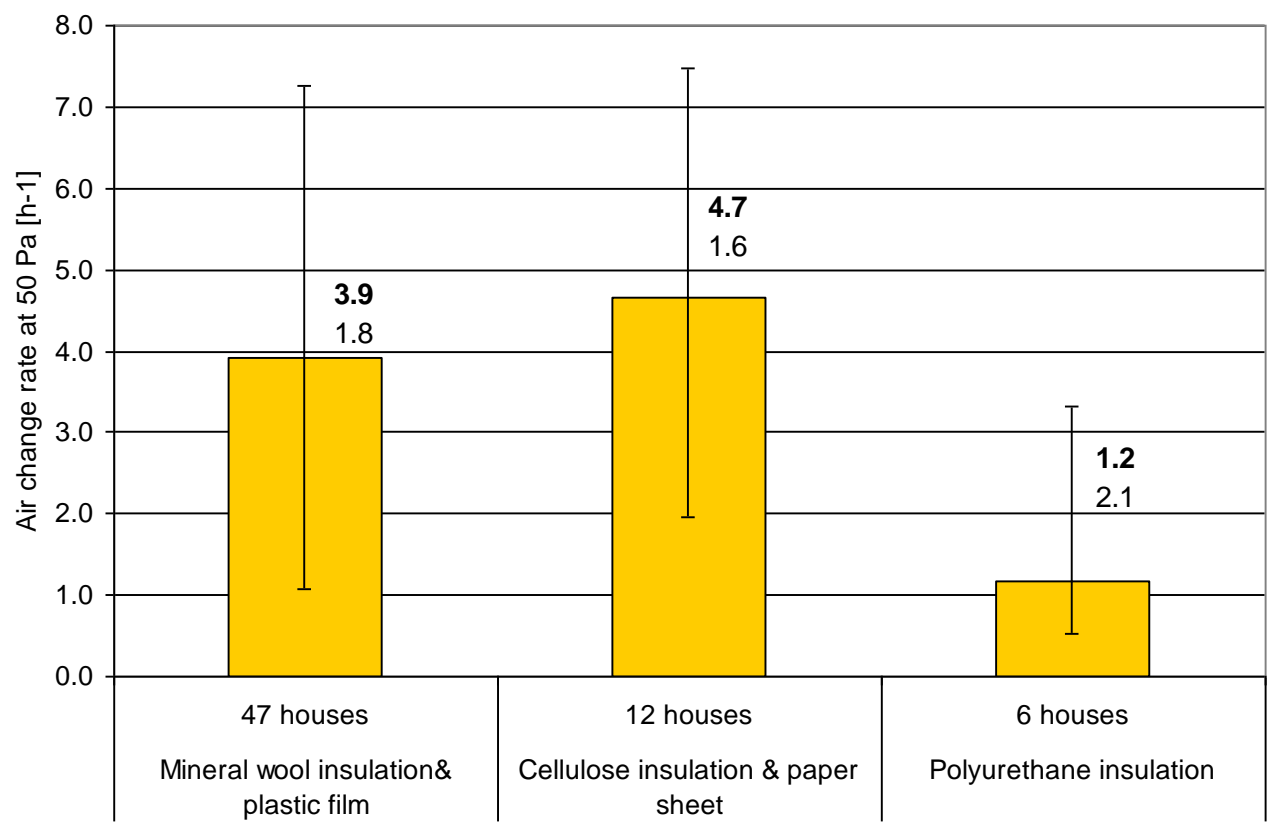

Figure 6. Air change rate at $50 \mathrm{~Pa}\left[\mathrm{~h}^{-1}\right]$ of timber-framed houses grouped by combinations of insulation and air barrier materials. Bold numbers indicate the average values and regular numbers beneath show standard deviations. "Whiskers" show the range of the results.

The influence of technology of construction on the airtightness of timber-framed buildings was also studied (Figure 7). Generally, prefabricated element houses (including large elements, small elements and pre-cut elements in platform construction) were significantly airtighter than the houses built on-site (t-test: $\mathrm{n}_{50}, \mathrm{p}$ value $<0.001 ; \mathrm{q}_{50}$ : $\mathrm{p}$-value $\left.<0.01\right)$.

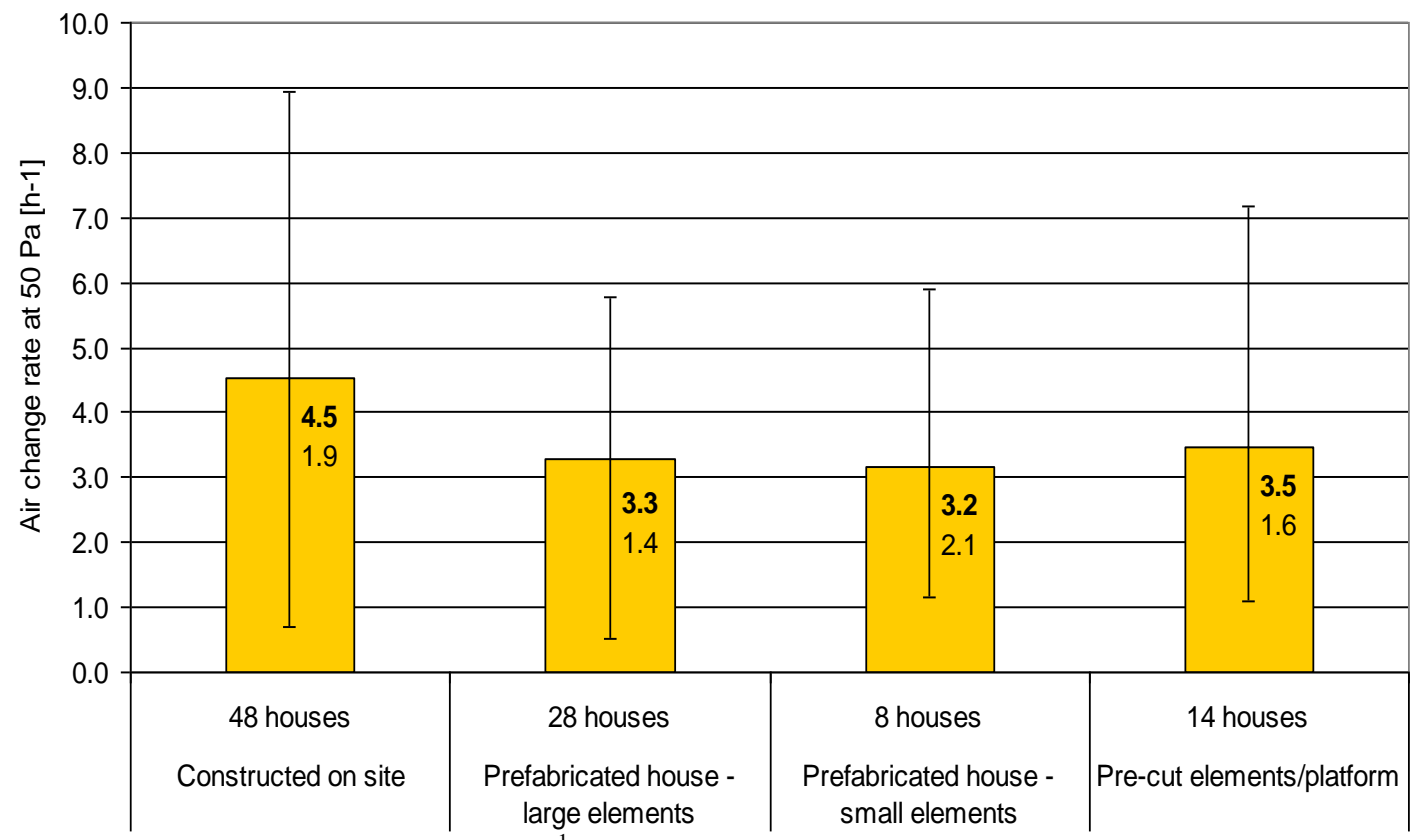

Figure 7. Air change rate at $50 \mathrm{~Pa}\left[\mathrm{~h}^{-1}\right]$ of timber-framed houses grouped by technology of construction. Bold numbers indicate the average values and regular numbers beneath show standard deviations. "Whiskers" show the range of the results. 
In Figures 8 and 9 only the timber-framed dwellings with mineral wool insulation and plastic film air barrier are grouped. This comparison represents better the possible influence of technology of construction (Figure 8) and ventilation system (Figure 9), because the impact of different insulation and air seal materials is eliminated. On the other hand the amount of some subgroups is very small.

Also in this comparison prefabricated element houses (large elements, small elements and pre-cut elements) were more airtight than those built on site, but the difference is smaller. Only the average air change rates $\left(\mathrm{n}_{50}\right.$-values) were statistically significant (t-test: $\mathrm{n}_{50}$ : $\mathrm{p}$-value $\left.<0.05\right)$ in this comparison. Group of five houses made by pre-cut technique appeared to be more airtight than other groups in Figure 8.

The difference between different ventilation systems of timber-framed houses with mineral wool insulation and plastic film (Figure 9) is not statistically significant compared to differences in the whole group of timber-framed houses (Figure 5).

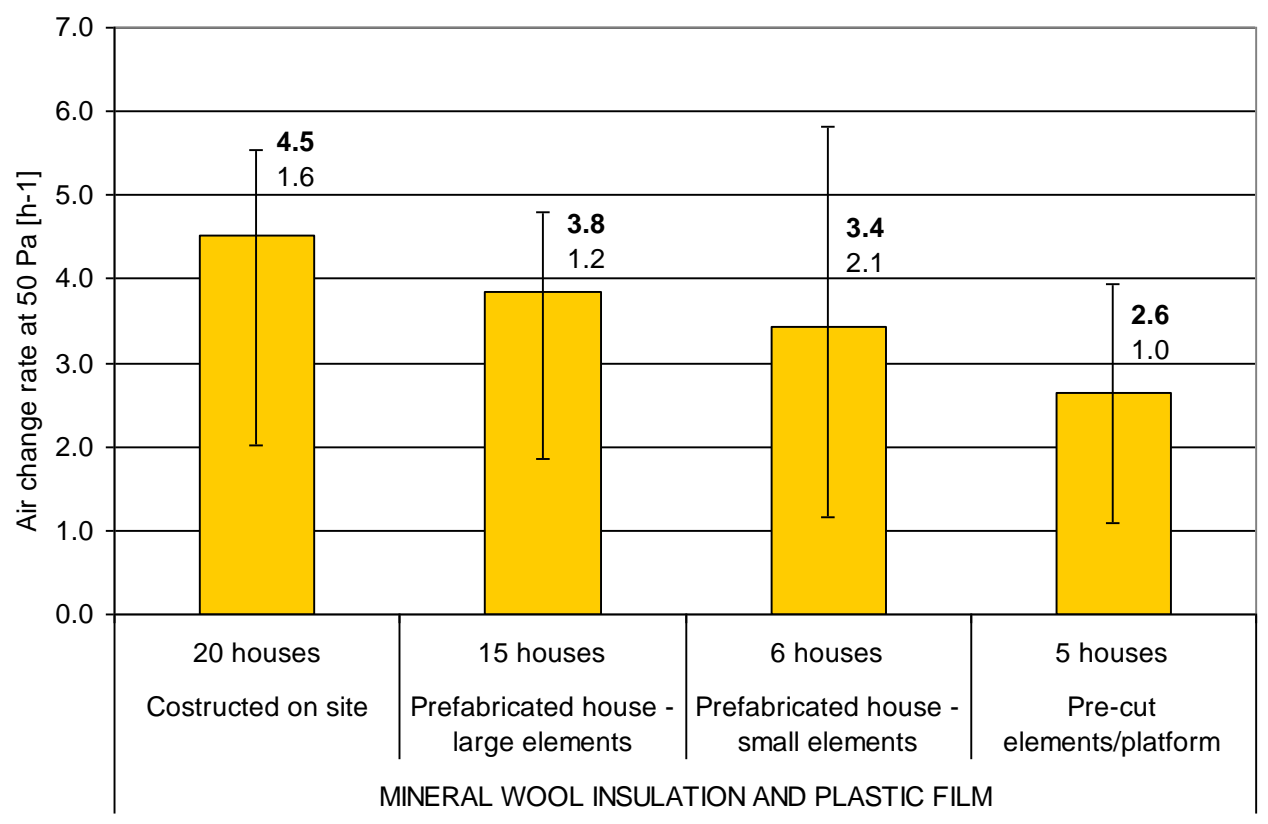

Figure 8. Air change rate at $50 \mathrm{~Pa}\left[\mathrm{~h}^{-1}\right]$ of timber-framed houses with mineral wool and plastic film grouped by technology of construction. Bold numbers indicate the average values and regular numbers beneath show standard deviations. "Whiskers" show the range of the results. 


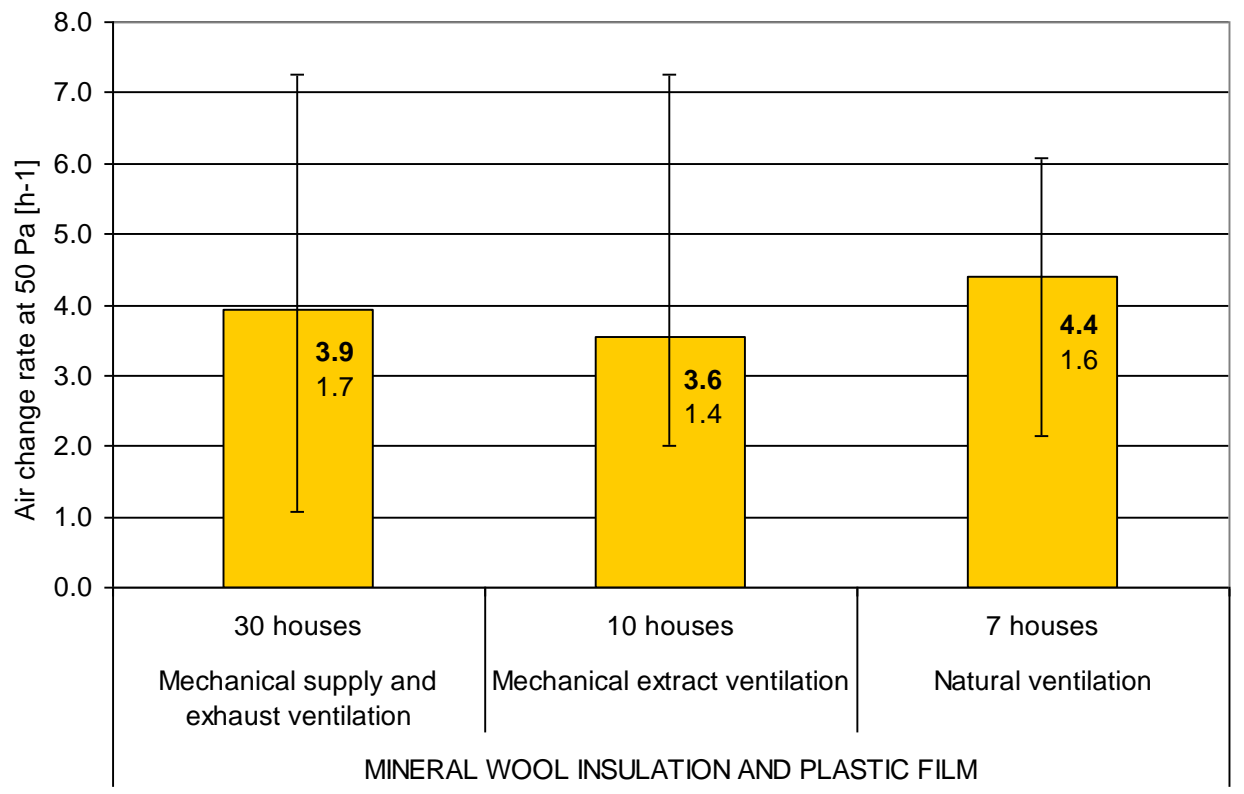

Figure 9. Air change rate at $50 \mathrm{~Pa}\left[\mathrm{~h}^{-1}\right]$ in timber-framed houses with mineral wool and plastic film grouped by ventilation system. Bold numbers indicate the average values and regular numbers beneath show standard deviations. "Whiskers" show the range of the results.

For achieving good airtightness it is important to pay attention to joints for example in the ceiling, walls, intermediate floors and windows. Airtight air barrier is difficult to achieve especially in the joint of intermediate floor and exterior wall. The influence of storeys was statistically insignificant on timberframed houses with mineral wool insulation and plastic film air barrier. In houses constructed on site the difference in airtightness between one-storey houses (average $4.0 \mathrm{~h}^{-1}$ ) and two-storey houses (average $5.0 \mathrm{~h}^{-}$ ${ }^{1}$ ) was greater but also statistically insignificant. The volume of the dwellings did not have any effect on the results. Ten most airtight timber-framed houses $\left(\mathrm{n}_{50}<1.5 \mathrm{~h}^{-1}\right)$ are presented in Table 5 .

Table 5. Ten most airtight timber-framed houses (air change rate under $1.51 / \mathrm{h}$ ).

\begin{tabular}{|c|c|c|c|c|c|c|c|}
\hline $\begin{array}{l}\text { House } \\
\text { code }\end{array}$ & $\begin{array}{l}\mathrm{n}_{50} \\
{[1 / \mathrm{h}]}\end{array}$ & Insulation material & Air barrier & $\begin{array}{l}\text { Construction } \\
\text { type }\end{array}$ & \begin{tabular}{|l|}
$\begin{array}{l}\text { Ventilation } \\
\text { system }\end{array}$ \\
\end{tabular} & $\begin{array}{l}\text { Construction } \\
\text { year }\end{array}$ & Storeys \\
\hline 1039 & 0.5 & PU & - & PL & MSE & 1990 & 1 \\
\hline 1005 & 0.6 & PU & - & PL & MSE & 2002 & 2 \\
\hline 2052 & 0.6 & PU & - & PL & MSE & 2003 & 1.5 \\
\hline 1020 & 0.7 & PU & - & CS & $\mathrm{ME}$ & 1999 & 2 \\
\hline 1023 & 1.0 & $\mathrm{CE}$ & $\begin{array}{l}\text { PF on ceiling, } \\
\text { GB on walls } \\
\end{array}$ & CS & MSE & 2002 & 1.5 \\
\hline 1012 & 1.1 & MW & PF & $\mathrm{PC}$ & MSE & 2001 & 1.5 \\
\hline 1029 & 1.2 & MW & $\mathrm{PF}$ & PS & MSE & 2000 & 1 \\
\hline 2039 & 1.2 & MW & PF & PS & MSE & 1999 & 1 \\
\hline 2037 & 1.2 & $\begin{array}{l}\mathrm{MW}+\mathrm{CE}+\text { partly } \\
\text { on ceiling also } \mathrm{PU}\end{array}$ & $\mathrm{PF}$ & $\mathrm{CS}$ & MSE & 2001 & 1 \\
\hline
\end{tabular}




\begin{tabular}{|c|c|c|c|c|c|c|c|}
\hline 1038 & 1.3 & PU & - & PS & MSE & 1997 & 1.5 \\
\hline \multicolumn{4}{|c|}{$\mathrm{PU}=$ polyurethane } & \multicolumn{4}{|c|}{$\mathrm{PL}=$ prefabricated - large elements } \\
\hline \multicolumn{3}{|c|}{$\mathrm{MW}=$ mineral wool } & $\mathrm{PF}=$ plastic film & \multicolumn{4}{|c|}{$\mathrm{PS}=$ prefabricated - small elements } \\
\hline \multicolumn{3}{|c|}{$\mathrm{CE}=$ cellulose } & GB = gypsum board & \multicolumn{4}{|c|}{$\mathrm{CS}=$ constructed on site } \\
\hline \multirow{2}{*}{\multicolumn{7}{|c|}{ MSE $=$ mechanical supply and exhaust }} & \\
\hline & & & & & & & \\
\hline
\end{tabular}

It can be noticed that among the most airtight timber-framed houses there are houses with different properties. This and the variation of the results in same kind of houses express the importance of construction quality in achieving good airtightness.

\subsubsection{Influence of type of ceiling of heavyweight houses}

Also the heavyweight detached houses were studied more thoroughly. The influence of the ceiling type was investigated because according to thermal imaging the joint between the ceiling and the outer wall is the most common place for air leakages.

The results of the comparison of the heavyweight houses with concrete-based and timber-framed ceiling structure are given in Table 6. Only those groups of houses with both ceiling structures are compared. Based on the results the ceiling structure has an influence on airtightness. On average the $\mathrm{n}_{50}$-values in the houses with concrete ceiling structure were smaller than in the houses with timber-framed ceiling structure although it should be noticed that the amount of the houses in compared groups were relatively small. In the whole sample the $\mathrm{n}_{50}$-values and $\mathrm{q}_{50}$-values of timber-framed and concrete ceiling structures were statistically significant (t-tests: $\mathrm{n}_{50}, \mathrm{p}$-value $<0.01 ; \mathrm{q}_{50}, \mathrm{p}$-value $<0.05$ ). Thermographic pictures revealed the ceiling-wall joint to be the most common location of air-leakage in all structures. Although the sample size was small, the results show trend that using a timber-framed ceiling increased the air change rate and air permeability of heavyweight building. Therefore, it is especially important to seal carefully the joints of heavyweight wall structure and timber-framed ceiling structure [19]. Relatively homogenous concretebased material wall-ceiling joints were found to be more airtight.

Table 6. Air change rates at $50 \mathrm{~Pa}\left[\mathrm{~h}^{-1}\right]$ of houses with concrete-based or timber-framed ceiling structure.

\begin{tabular}{|l|c|c|c|c|c|c|}
\hline \multirow{2}{*}{ Type of house } & \multicolumn{3}{|l|}{ Houses with concrete or AAC ceiling } & \multicolumn{3}{l|}{ Houses with timber-framed ceiling } \\
\cline { 2 - 7 } & $\begin{array}{l}\text { Amount of } \\
\text { houses }\end{array}$ & $\begin{array}{l}\text { Average } \\
\mathrm{n}_{50} \text {-value } \\
{\left[\mathrm{h}^{-1}\right]}\end{array}$ & $\begin{array}{l}\text { Average } \\
\mathrm{q}_{50} \text {-value } \\
{\left[1 / \mathrm{sm}^{2}\right]}\end{array}$ & $\begin{array}{l}\text { Amount of } \\
\text { houses }\end{array}$ & $\begin{array}{l}\text { Average } \\
\mathrm{n}_{50} \text {-value } \\
{\left[\mathrm{h}^{-1}\right]}\end{array}$ & $\begin{array}{l}\text { Average } \\
\mathrm{q}_{50} \text {-value } \\
{\left[1 / \mathrm{sm}^{2}\right]}\end{array}$ \\
\hline $\begin{array}{l}\text { Autoclaved } \\
\text { aerated concrete }\end{array}$ & 9 & 1.5 & 1.6 & 1 & 2.3 & 2.0 \\
\hline $\begin{array}{l}\text { Shuttering } \\
\text { concrete block }\end{array}$ & 3 & 1.2 & 1.6 & 7 & 1.8 & 2.0 \\
\hline $\begin{array}{l}\text { Concrete element } \\
\text { Lightweight }\end{array}$ & 2 & 1.2 & 1.6 & 8 & 3.0 & 3.0 \\
\hline aggregate concrete & 1 & 1.9 & 2.4 & 9 & 3.3 & 3.8 \\
\hline Total & $\mathbf{1 5}$ & $\mathbf{1 . 5}$ & $\mathbf{1 . 8}$ & $\mathbf{2 5}$ & $\mathbf{2 . 6}$ & $\mathbf{2 . 7}$ \\
\hline
\end{tabular}

\subsubsection{Discussion on single-family houses}

It should be noted that the sample size (amount of houses) in some detailed comparison is relatively low and, as is general in field studies, all influential factors of air-tightness could not be fully controlled. However, real buildings in real environment were measured with an attempt to limit influential factors of airtightness as much as possible by carefully choosing case buildings. 
There is no limit value of air change rate $\mathrm{n}_{50}$ in National Building Code of Finland. The $\mathrm{n}_{50}$-value i.e. air change rate at $50 \mathrm{~Pa}$ is recommended to be as near as possible to the value of one air change per hour in order to guarantee a proper function of ventilation devices [9]. The results of the research showed that actual air change rates do not reach the recommended value of one air change rate per hour.

Part D3 of the National Building Code of Finland, published in 2007 [10] took into consideration leakage air flow in compensation calculation of heat loss. The basic value for $\mathrm{n}_{50}$ was $4.0 \mathrm{~h}^{-1}$. The lower $\mathrm{n}_{50^{-}}$-value can be used if it is determined by measurement or by some other way. In newer part of D3, published in 2010 [19] the basic value for $n_{50}$ was $2.0 \mathrm{~h}^{-1}$. In Finnish passive house the air change rate, $\mathrm{n}_{50}$ has to be lower than $0.6 \mathrm{~h}^{-1}$. The basic value of $\mathrm{n}_{50}$ of Finnish Code in $2007\left(4.0 \mathrm{~h}^{-1}\right)$ is near the mean air change rate of the measured timber-framed houses $\left(3.9 \mathrm{~h}^{-1}\right)$. In current part D3 of the Finnish Code, instead the air leakage index, $\mathrm{q}_{50}$ could be normally up to $4 \mathrm{~m}^{3} /\left(\mathrm{hm}^{2}\right)$. This could be exceeded only if demanding structural solutions worsen the airtightness of a building significantly [20].

In Swedish regulations [21] the requirement of airtightness for dwellings is $0.8 \mathrm{~L} / \mathrm{sm}^{2} .38 \%$ of the houses in current study had lower air permeability than required in Sweden. $10 \%$ of the houses filled the requirement created by Natural Resources Canada in R-2000 standard [22]. In the future the nearly-zero energy buildings will be airtighter and the air change rates of these houses will be likely to fulfil past and current recommendations.

\subsection{Apartments}

\subsubsection{Influence of external wall structures}

The air change rates of the measured apartments in apartment buildings were on average smaller than the air change rates of single-family detached buildings. The average air change rate $\mathrm{n}_{50}$ of all studied apartments was $1.6 \mathrm{~h}^{-1}$ ranging from 0.3 to $5.3 \mathrm{~h}^{-1}$. The air change rate of an apartment includes the air leakages between measured apartment, adjacent apartments and a staircase. The average area of the apartments was $72 \mathrm{~m}^{2}$ ranging from 35 to $138 \mathrm{~m}^{2}$. The air change rate of $49 \%$ of the measured apartments was below $1 \mathrm{~h}^{-1}$. Figure 10 shows the air change rates of apartment groups based on the structures of multiapartment buildings.

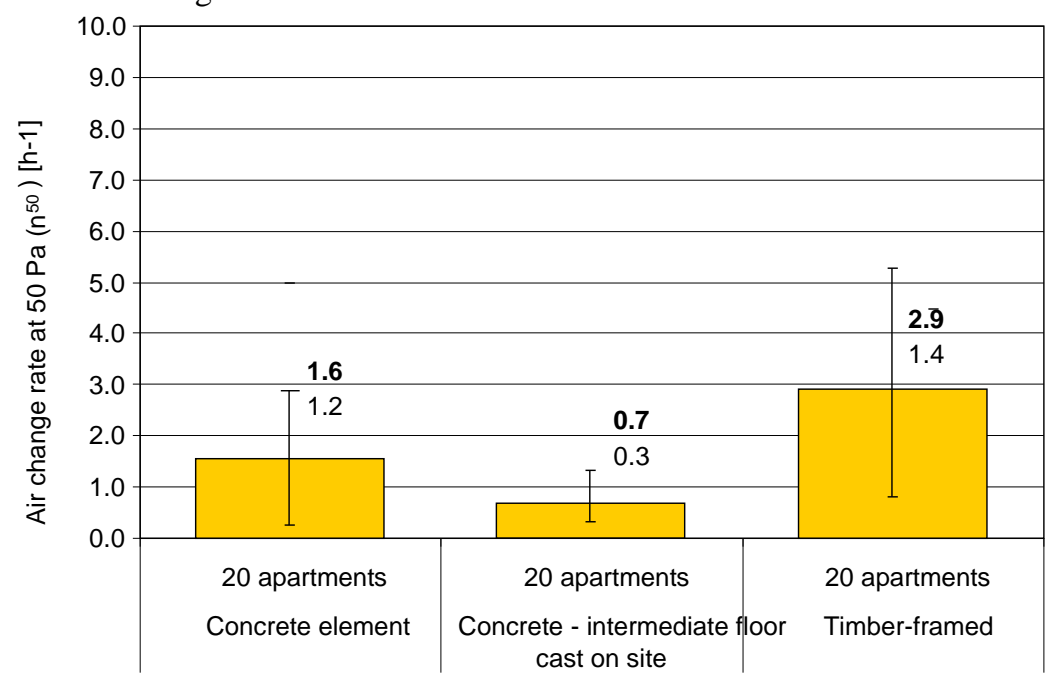

Figure 10. Air change rates of apartments in multi-apartment buildings normalised by indoor volume $\left(\mathrm{n}_{50}\right)$. Bold numbers indicate the average values and regular numbers beneath show standard deviations. "Whiskers" show the range of the results.

In this comparison the apartments in timber-framed apartment buildings were less airtight than apartments in precast concrete element buildings. This trend matched the findings from single family detached buildings (Figure 3 ) and appeared to be more clearly visible in the comparison of apartment buildings. Very 
good average airtightness with small deviation was reached in apartments of precast concrete apartment buildings with cast on site intermediate floors.

\subsubsection{Comparison of airtightness between blower door and air supply unit}

The airtightness of whole staircase was also measured in the study. For comparison purposes the pressure differences and corresponding leakage air flow rates were measured by the air supply unit of the house and blower-door equipment (Figure 11). Average airtightness with blower-door method was $0.9 \mathrm{~h}^{-1}$ and with air supply unit $1.2 \mathrm{~h}^{-1}$. The difference of the results was found to be not significant. The $\mathrm{n}_{50^{-}}$ values of three measured apartments $\left(1.3 \mathrm{~h}^{-1}, 4.3 \mathrm{~h}^{-1}\right.$ and $\left.1.7 \mathrm{~h}^{-1}\right)$ were higher than the $\mathrm{n}_{50}$-value of the whole staircase. The possible air flow from apartment to staircase or to apartments adjacent to the measured apartments has influence on air change rates.
- Air supply unit
- Blower door

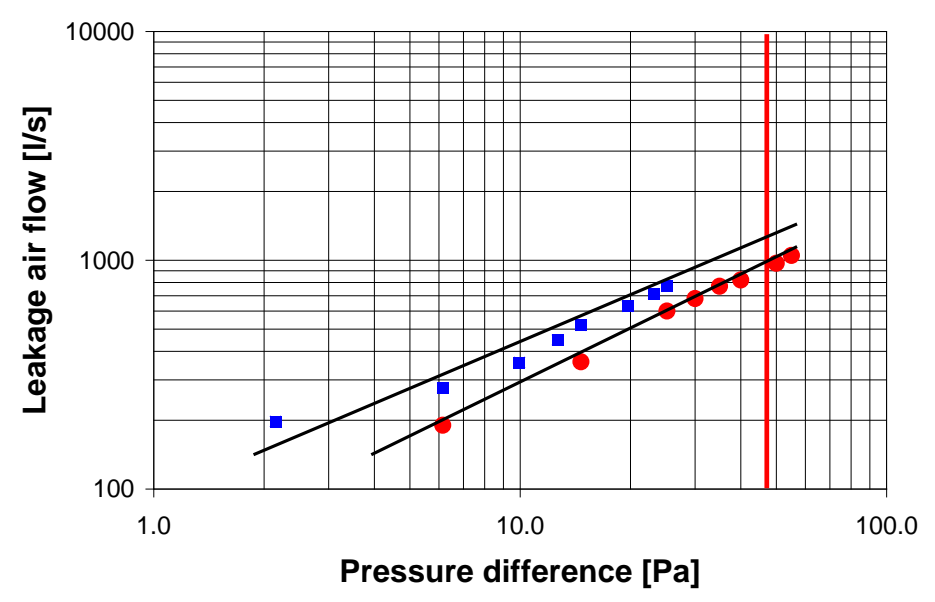

Figure 11. The leakage air flow of the staircase versus the pressure difference between indoor air and outdoor air.

\section{CONCLUSIONS}

The objective of study was to determine the present level of airtightness in modern residential buildings in Finland. The airtightness of 170 single-family houses and 56 apartments have been studied in two large-scale research projects between 2002-2009. The selection of single-family houses included 100 lightweight (timber-framed) and 70 heavyweight external-walled buildings (10 autoclaved aerated concrete (AAC) block, 10 lightweight aggregate concrete (LWAC) block, 10 brick masonry, 10 shuttering concrete block, 10 concrete element and 20 log houses). Starting from the group of most airtight the mean air change rate $\mathrm{n}_{50}$ of measured AAC block houses was $1.5 \mathrm{~h}^{-1}\left(\mathrm{q}_{50}: 1.7 \mathrm{~m}^{3} /\left(\mathrm{hm}^{2}\right)\right)$, shuttering concrete block houses $1.6 \mathrm{~h}^{-1}\left(1.9 \mathrm{~m}^{3} /\left(\mathrm{hm}^{2}\right)\right)$, concrete element houses $2.6 \mathrm{~h}^{-1}\left(2.7 \mathrm{~m}^{3} /\left(\mathrm{hm}^{2}\right)\right)$, brick houses $2.8 \mathrm{~h}^{-1}\left(3.0 \mathrm{~m} \mathrm{~m}^{3} /\left(\mathrm{hm}^{2}\right)\right)$, LWAC houses $3.2 \mathrm{~h}^{-1}\left(3.7 \mathrm{~m}^{3} /\left(\mathrm{hm}^{2}\right)\right)$, timber-framed houses $3.9 \mathrm{~h}^{-1}\left(3.9 \mathrm{~m}^{3} /\left(\mathrm{hm}^{2}\right)\right)$ and log houses $6.0 \mathrm{~h}^{-1}$ $\left(5.7 \mathrm{~m}^{3} /\left(\mathrm{hm}^{2}\right)\right.$ ). Single-family concrete and masonry houses (mean $\mathrm{n}_{50}$-value $2.3 \mathrm{~h}^{-1}$ ) were on average more airtight than log houses $\left(6.0 \mathrm{~h}^{-1}\right)$ and timber-framed houses $\left(3.9 \mathrm{~h}^{-1}\right)$. The differences between the house groups are slightly smaller when comparing the corresponding $\mathrm{q}_{50}$-values $\left(2.6 \mathrm{~m}^{3} /\left(\mathrm{hm}^{2}\right) \mathrm{vrs} .5 .7 \mathrm{~m}^{3} /\left(\mathrm{hm}^{2}\right)\right.$ vrs. $\left.3.9 \mathrm{~m}^{3} /\left(\mathrm{hm}^{2}\right)\right)$. The concrete and masonry houses with concrete ceiling structure were on average airtighter than the concrete and masonry houses with timber-framed ceiling structures. The difference of air change rates of the concrete and masonry houses with slab-on ground and with concrete crawl space was not significant. The same result was noticed when concerning timber-framed detached houses. The air change rates of multi-storey concrete and masonry houses were lower than of one-storey concrete and masonry houses. The opposite was noticed in timber-framed houses. The difference was a consequence of the fact that jointing of intermediate floor and wall structure weakened air-tightness of the measured timber-framed houses. Log houses with modern seam insulation (cellular rubber or plastic insulation) were airtighter than those with traditional seam insulation (mineral wool, flax insulation, polypropylene). Also 
the type of insulation (some of the log houses had the ceiling structure with polyurethane insulation) could have effect on the airtightness in some of the log houses.

Very good airtightness was reached with many different combinations of insulation and air barrier materials and with houses of different age, storeys and construction type. This and the range of results in same group of houses indicate the importance of construction quality in achieving good airtightness.

Also, the airtightness of 56 apartments were measured in 16 multi-family apartment buildings. The mean $\mathrm{n}_{50}$-value of 20 apartments in precast concrete element buildings (both in walls and floors) was $1.6 \mathrm{~h}^{-}$ ${ }^{1}$. Corresponding $\mathrm{n}_{50}$-value of 23 apartments in apartment buildings with precast concrete element walls and cast on site floors was $0.7 \mathrm{~h}^{-1}$. The mean $\mathrm{n}_{50}$-value of 16 apartments in timber-framed (both in walls and floors) apartment buildings was $2.6 \mathrm{~h}^{-1}$. The air change rate of the whole staircase was $0.9 \mathrm{~h}^{-1}$ by using Blower-door system and $1.2 \mathrm{~h}^{-1}$ by using air supply unit of the building. The $\mathrm{n}_{50}$-value of the whole staircase was lower than the $\mathrm{n}_{50}$-values of the measured apartments. The air change rate of apartment includes the air leakages between measured apartment, adjacent apartments and a staircase.

\section{ACKNOWLEDGMENTS}

These researches have been financed by Tekes (Finnish Funding Agency of Technology and Innovation) and the group of Finnish companies and associations. Measurements were done by researchers in the Department of Civil Engineering/ Structural Engineering at Tampere University of Technology and in the Department of Energy Technology/ Heating Ventilating and Air-Conditioning at former Helsinki University of Technology (now Aalto University). We extend our thanks to all assisting people, residents of the studied houses and financiers of the research for their co-operation during the studies. 


\section{REFERENCES}

[1] European Parliament. Directive 2002/91/EC of the European Parliament and of the Council of 16 December 2002 on the energy performance of buildings; Directive 2010/31/EC of the European Parliament and of the Council of 19 May 2010 on the energy performance of buildings (recast), 2010.

[2] Emmerich, S.J., Persily, A.K., McDowell, T.P. 2005. Impact of infiltration on heating and cooling loads in U.S. office buildings. Building and Fire Research Laboratory, National Institute of Standards and Technology Gaithersburg, MD USA TESS, Inc., Madison, WI USA.

[3] Chan, W.R., Nazaroff, W.W., Price, P.N., Sohan, M.D., Gadgil, A.J. 2005. Analyzing a database of residential air leakage in United States. Atmos Environ, 39, pp. 3445-3455

[4] Kalamees, T. 2007. Air tightness and air leakages of new lightweight single-family detached houses in Estonia. Build Environ, 42 (6), pp. 2369-2377

[5] Sherman, M.H., Dickerhoff, D.J. 1998. Air tightness of USA dwellings. ASHRAE Trans, 104 (2), pp. 1359-1367.

[6] Sfakianaki, A., Pavlou, K., Santamouris, M., Livada, I., Assimakopoulos, M., Mantas, P. et al. 2008. Air tightness measurements of residential houses in Athens, Greece. Build Environ, 43, pp. 398-405.

[7] Alfano, F.R.d'Ambrosio, Dell'Isola, M., Ficco, G., Tassini, F. 2012. Experimental analysis of air tightness in Mediterranean buildings using the fan pressurization method. Building and Environment, Volume 53, Pages 16-25, ISSN 0360-1323, http://dx.doi.org/10.1016/j.buildenv.2011.12.017.

[8] Chen, S., Levine, M. D., Li, H., Yowargana, P., Xie, P. 2012. Measured air tightness performance of residential buildings in North China and its influence on district space heating energy use. Energy and Buildings. Volume 51, August 2012, Pages 157-164, http://dx.doi.org/10.1016/j.enbuild.2012.05.004.

[9] The National Building Code of Finland, part C3. 2007. Thermal insulation of building, requirements, Ministry of the Environment. Helsinki, Finland. (Suomen rakentamismääräyskokoelma, osa C3. 2007. Rakennuksen lämmöneristys, määräykset). (In Finnish). 9 p.

[10] The National Building Code of Finland, part D3. 2007. Energy efficiency of buildings, requirements and guidelines. Ministry of the Environment. Helsinki, Finland. (Suomen rakentamismääräyskokoelma, osa D3. 2007. Rakennusten energiatehokkuus, määräykset ja ohjeet, Ympäristöministeriö). (In Finnish). 12 p.

[11] Vinha, J., Korpi M., Kalamees T., Eskola L., Palonen J., Kurnitski J., Valovirta I., Mikkilä A. \& Jokisalo J. 2005. Heat and moisture conditions, ventilation and airtightness of timber-frame singlefamily detached houses. Research report 131. Tampere University of Technology, Finland. (Puurunkoisten pientalojen kosteus- ja lämpötila-olosuhteet, ilmanvaihto ja ilmatiiviys). (In Finnish). 102 p. + app. 10 p.

[12] Vinha J., Korpi M., Kalamees T., Jokisalo J., Eskola L., Palonen J., Kurnitski J., Aho H., Salminen M., Salminen K. \& Keto M. 2009. Airtightness, indoor climate, and energy economy of detached houses and apartments. Research report 140. Tampere University of Technology, Finland. (Asuinrakennusten ilmanpitävyys, sisäilmasto ja energiatalous). (In Finnish). 148 p. + app. 19 p.

[13] Vinha, J., Korpi, M., Salminen, K. \& Kurnitski, J. 2010. Air tightness of residential buildings in Finland. Proceedings of International Conference on Building Envelope Systems and Technologies, ICBEST 2010, Vancouver, Canada, Vol. 2, pp. 279-280.

[14] Kalamees, T., Korpi, M., Eskola, L., Kurnitski, J. \& Vinha, J. 2008. The distribution of the air leakage places and thermal bridges in Finnish detached houses and apartment buildings. Proceedings of the 8th Symposium on Building Physics in the Nordic Countries (C. Rode, editor). Report R-189. Technical University of Denmark, Copenhagen, Kgs. Lyngby, pp. 1095-1102.

[15] Korpi, M., Vinha, J. \& Kurnitski J. 2008. Airtightness of single-family houses and apartments. Proceedings of the 8th Symposium on Building Physics in the Nordic Countries (C. Rode, editor). Report R-189. Technical University of Denmark, Copenhagen, Kgs. Lyngby, pp. 1397-1404.

[16] EN 13829. 2000. Thermal performance of buildings - Determination of air permeability of buildings - Fan pressurization method . European committee for standardization. 24 p.

[17] SS 0215 51. 1987. Buildings - Determination of airtightness. SIS. The Standardization Commission in Sweden. Sweden. 
[18] Aho, H., Vinha, J. \& Korpi, M. 2008. Implementation of airtight constructions and joints in residential buildings. Proceedings of the 8th Symposium on Building Physics in the Nordic Countries (C. Rode, editor). Report R-189. Technical University of Denmark, Copenhagen, Kgs. Lyngby, pp. 1405-1412 .

[19] The National Building Code of Finland, part D3. 2010. Energy efficiency of buildings. Ministry of the Environment. Helsinki, Finland. (Suomen rakentamismääräyskokoelma, osa D3. 2010. Rakennusten energiatehokkuus, määräykset ja ohjeet, Ympäristöministeriö.) (In Finnish). 14 p.

[20] The National Building Code of Finland, part D3. 2012. Energy efficiency of buildings. Ministry of the Environment. Helsinki, Finland. (Suomen rakentamismääräyskokoelma, osa D3. 2010. Rakennusten energiatehokkuus, määräykset ja ohjeet, Ympäristöministeriö.) (In Finnish). 35 p.

[21] Building Regulations. 2002. The National Board of Housing, Building and Planning in Sweden (Boverkets Byggregler, BBR. 2002 Boverkets byggregler - BFS 1993:57 med ändringar till och med 2002:19. Boverket). (In Swedish)

[22] R-2000 Standard. 2001. Natural Resources Canada. 